\title{
Hands and feet: A reflection on Polynesian navigation-a Niue Fakafifine community practitioner perspective in Aotearoa-New Zealand
}

As a community navigator, my practice draws from skills, knowledge and principles of Polynesian navigation such as wayfinding ${ }^{1}$. In this essay, I will provide personal experiences that have influenced and nurtured me in my development as a community navigator. I will discuss four influences of Polynesian practices: dance, weaving, storytelling and navigation. These are concepts that I draw from to support people who experience hardship in life and are intrinsically connected and complementary of one another when applied in my practice.

People of the Pacific are inherently tied to the Ocean. Ancient Polynesians navigated open Ocean in search of new lands and were genius and master navigators. Without instruments, they used observations of the stars, sun, ocean swells and other signs of nature. Navigation is an art and precise science, passed down verbally from navigator to navigator over generations (Low, 1983). An essential skill in Polynesian navigation is wayfinding, and

\footnotetext{
${ }^{1}$ Wayfinding - Modern methods and techniques of non-instrument navigation, based on Pacific traditions

In 2019, Phylesha was invested as a Member of the New Zealand Order of Merit for services to the Pacific and LGBTQI+ communities (Government House, 2019). Phylesha is currently a first-year Master of Applied Indigenous Knowledge student at Te Wānanga o Aotearoa in Māngere.
} 
it comprises of three components: 1. Designing a course strategy - knowing where you are heading to; 2 . Maintaining as close to the course or pathway as possible - no deviation from the course strategy; 3. Finding land - arriving at your destination and completion of the voyage (Polynesian Voyaging Society, 2020). Polynesian dance, weaving and storytelling follow the same components of navigation wayfinding in practice.

\section{Tulai o ho! Puipui o! \\ Monu! Monu! Monu Tagaloa!}

The above is a chant in the Niue language that begins as a call to people, acknowledging the creator Tupua Tagaloa ${ }^{2}$ firstly, the Principal ancient god to Niue peoples in pre-missionary times (Sperlich, 1997). It translates to Come together, Gather hither! Bless Tagaloa!

Koe haaku e higoa ko My name is Phylesha Phylesha Brown-Acton Brown-Acton (Ikinepule). (Ikinepule).

Koe tau matua tupuna My grandparents were haaku ko Ikipule mo Ikipule and Trixie Etuata. Tulikiti Etuata.

Koe matua fifine haaku ko My mother is Merry Chris Melekulisi Ikinepule. Ikinepule.

Koe Magafaoa haaku ko My extended families are Etuata, Galiki mo Etuata, Galiki and Ikinepule. Ikinepule.

Hau au he maaga ko I come from the village of 'Fineone Hakupu Atua. 'Fineone Hakupu Atua.

2 Tupua: Ancient god, Tagaloa: Principal god of Niueans in premissionary times. 
Koe motu haaku ko My Island is Nukututaha Nukututaha-Niue. (the land that stands alone) - Niue.

Niue is my land, Niue is my home Aue tulou.

\section{The year of 1976}

I was born February of 1976 in central suburbs of Tāmaki Makaurau at St Helen's Hospital. Close in proximity to Te Wai Orea (Western Springs Lake), the lake that gathers rainwater from the slopes of Te Tatua-a-Riukiuta (Three Kings), Ōwairaka or Te Ahi-kā-a-Rakataura (Mt Albert) and Maungawhau (Mt Eden) mountains. St Helens Hospital was first opened in Pitt Street in 1905 by former Prime Minister Richard Seddon, previously known as the former Auckland Maternity Hospital, replaced by National Women's Hospital in the late 1940s. St Helens Hospital was moved to Western Springs in 1968 and closed in 1990 (Ministry of Culture and Heritage, 2018). My mother, a Niuean woman, born in Niue, my father, an English/Irish/Scottish man born and raised in New South Wales, Australia. Not the desired partnership my mother's father would approve. My grandfather would cut ties with my mother for some time as a result of this partnership. My mother had five children; my elder siblings lived with my grandparents in Niue. I am my father's first child, followed by two younger brothers. My two brothers and I were the first children in all generations of my maternal lineage that were half Niuean and European.

My father was an alcoholic and violent towards my mother. I have very little to no knowledge about his family or his upbringing, and It did not take long before we packed our bags and left. Auckland Central suburbs was the epicentre for Pacific families from the 1950's to the 
late 1970s. I was raised in the chaos of city life during the Dawn Raids. I spent most of my time as a young person living with extended family as no one knew what to do with me. It was self-evident from a young age that I was overtly and unapologetically feminine and the complete opposite of my masculine brothers. My mother was a single parent raising six of her children, working two jobs and could not manage me let alone deal with the pressures of other family members wishing to beat the femininity out of me.

My grandfather's elder sister, Mrs Atalini Kepu, raised me. She was a devout founding member of the Newton Pacific Islanders Congregational Church (P.I.C.C.)-Niue Congregation. She was the aunty that would kiss you upon arrival, but her kisses were not on your cheek or forehead, she would breathe deeply inwards and hold you - an Indigenous way of greeting a person and their ancestors ${ }^{3}$. She was home proud, and her cabinetry was full to the brim with Crown Lynn Sesame Street and Annie ceramic dinnerware sets and dishes, some fine bone china and crystal glassware. Aunty Ata cherished the things she worked hard to acquire and brought them out only for distinguished guests.

Mr Kosene Kepu was Aunty Ata's husband. Aunty Ata never had children. In the late 1940s, my grandfather and Aunty Ata plotted a deceiving plan, telling my grandmother that Aunty Ata would take baby Trevor (my mother's younger brother) so he could be weaned off breastfeeding and returned later in the year. Aunty Ata and baby Trevor left Niue aboard the Tofua ship bound for Auckland City never to return home to Nena. Nena composed a song called "Haaku Lupe" (My pigeon) (M.C. Ikinepule, personal communication, March 20, 2020) and described her pain about being lied too and her baby

3 That is how our elders would greet us, they never kissed us, it was a deeper connection to you and your ancestors (M.C. Ikinepule, personal communication, March 20, 2020). 
pigeon never returning home to her, my extended family still sing this song today. Aunty Ata did not steal me, I was lent to Aunty Ata to aide her in her old age and to provide me with refuge from those who did not understand nor accept me.

I spent most of my weekends in the laundry room doing the family laundry using an old 1950's Fisher \& Paykel wringer washing machine. I lost count how many times that machine electrocuted me, live wires exposed, lots of manual emptying of water between wash and rinse cycles - it was unsafe for a child to manage. I was never allowed friends as chores came first, and I had to pay my keep. I learnt many lessons from Aunty Ata, such as managing a home and preparing a feast with little ingredients. She was also very prim and proper and carried herself with pride in her home and appearance. I am grateful for the many lessons I have learnt from elders.

\section{The Dancer}

I never wanted to be a firefighter or a police officer like other children aspired to be. I was adamant that I was going to be a beautiful Polynesian dancer ${ }^{4}$. My mother, who I affectionately call "Girlfriend" is my best friend. She was born Christmas day 1947 in the village of Fineone Hakupu Atua, Niue Island. Mum arrived into the world birthed under the roof of a coconut thatched hut ${ }^{5}$, known as a Fale pola. She is the fourth child of eight, five brothers, two sisters, mum, is the youngest daughter. A strict father and loving mother, both my grandparents were hard workers on the land, sea and for their people.

\footnotetext{
${ }^{4}$ My mother would tell me that I was relentless and fixed in becoming a Polynesian dancer. She would dance with me and teach me different styles of Polynesian dance (M.C. Ikinepule, personal communication, March 20, 2020).

5 This was highlighted in our discussions and reflecting on modernisation. Mum was born in 1947 on soil in a fale pola and I was born in a hospital bed in a maternity ward in 1976 (M.C. Ikinepule, personal communication, March 20, 2020).
} 
Mum was a hard worker and never faulted her loyalty to her family, village and country.

"Haaku lima e moe hui e, My hands and feet, Haaku lima e moe hui e, My hands and feet, Haaku lima moe hui, My hands and feet, hands haaku lima moe hui and feet

Ke lagaki hake Fineone. Will lift up Fineone"6

The above text is a song composed by my mother's eldest brother that she would sing and to me as a child. Words that would become the foundations of my practice, something I would not begin to unpack until this moment. Throughout my life I would learn that my hands and my feet would be the two most useful tools for serving others, for feeding people, to weave a home, to build a canoe, to dance in honour of my people, village and culture and to stand strong.

The compositions of old Niue songs provide meaning and communicate the thoughts of the composer. My uncle Meke wrote this song for my village who performed at the South Pacific Arts Festival in Rarotonga, Cook Islands, in $1968^{7}$. This song provides a simple message to my people that we must work hard with our hands and feet to uplift our village name. My mother sang this as a song to me as a form of tacit knowledge. According to my mother, it means to work hard for your family and your village ${ }^{8}$. Songs like this made mum cheerful. It reminded her of home. A beautiful Niuean woman with thick black hair down to her ankles, striking bone structure and features,

${ }^{6}$ Song composed by Meke Ikinepule (1968) for the South Pacific Arts Festival, sung as a lullaby by Merry Chris Ikinepule (personal communication, March 2020).

7 Meleua Ikiua is my first cousin.

8 My mother explains the meaning of Haaku lima e mo hui e. (M.C.

Ikinepule, personal communication, March 20, 2020). 
this was my mother, and she was my ideal image of femininity, elegance and beauty.

As young as four years old, I was fascinated with my mother's beauty. I would sketch pictures of my mother on any surface or piece of paper or board, using pencil, crayon, pen and markers depicting her as a Polynesian dancer. I would tell myself when I grew up that I wanted to be just like my mother physically and internally.

I adored my mother's energy and spirit; she could make anyone feel welcome and relaxed. I would braid my mother's hair for hours as a child, and I refused to sleep unless I had my mother's hair in my hand or close to my face. I would fall asleep holding her hair many times dreaming of swaying my hips gracefully, dancing to the beats of drums, captivating the audience as I mesmerised them with my Polynesian beauty. My hair is a symbol that speaks about the special bond and relationship between my mother and me.

I travelled the world with dance, performing at prestigious dance festivals such as the Venice Biennale, also known as the "Art Olympics", the world's oldest arts festival which began in 1895 in Venice, Italy (Museum of New Zealand Te Papa Tongarewa, n.d.). I was a guest solo artist in a production by MAU Dance Company, called "Paradise", directed by Lemi Ponifasio. I performed with the company as the headline show for the Auckland Arts Festival (AK03) and the Equinox Dance Festival at the Tjibaou Cultural Centre in Noumea in 2003. I also performed as a member of the Fa'afafine Visual and Performing Arts Group "Pasifika Divas" at the Asia Pacific Triennial of Contemporary Art in Queensland in the International show "Island Divas" produced by Lisa Taouma. 


\section{The Master Weaver - Tufuga lalaga}

I was very fortunate to have been born Fakafifine ${ }^{9}$ for I was able to spend time with my elders, it was a natural occurrence as I liked to cook, clean and wait on elders or guests. My grandmother was a tall woman; she was always smiling, and I never witnessed emotions of anger or frustration from her. My grandmother was a well-loved and highly regarded woman. She worked hard and was a skilled Tufuga lalaga-master weaver. She taught many women how to weave, and how to cultivate and prepare the finest materials for weaving.

Weaving groups were a support network for women discussing how to raise a child or handle a husband and most importantly, to create art. Nena's weaving abilities gained her great respect among women, and she held many leadership roles voted by women in our village, this was a great sign of trust, respect and recognition by people in our village. Nena was the first elected woman from my village to the Assembly of Niue Government as a member of Parliament (M.C. Ikinepule, personal communication, March 20, 2020), and she was also the President of the Niue Women's Council. She was a member of the South Pacific Women's Council of Churches. They were instrumental in lobbying the World Council of Churches in Geneva for the right of women to vote in the male-dominated Councils of Churches during the 1960s - 1970s.

Navigation could not be achieved alone without the skill of weaving. Sails woven from the pandanus leaves, lashings were made from coconut husk fibres and woven into rope, the Kiato ${ }^{10}$ and Hama ${ }^{11}$ could not be fixed without using weaving techniques. Weaving requires excellent skill, just like navigation. You have to know how to start your weaving (course strategy), to follow a pattern

\footnotetext{
9 Fakafifine - to be effeminate.

10 Kiato - outrigger booms on the canoe.

${ }^{11}$ Hama - outrigger of a canoe.
} 
repetitiously (no deviation from the course strategy) until you arrive at the final strand to lock in place (finding land-arriving, completing the voyage), navigation and weaving are inseparable. My grandmother incorporated song and storytelling into her weaving; she was a composer of melody and an exemplar of wise words. These are words recited by my grandmother to five generations of her children.

"Sit at the feet of others,

When you sit at the feet of others, you learn without, Fear or anger, with an open heart and mind - be humble always". ${ }^{12}$

Nena passed away Monday 15 February 2010 - my birthday. Her words are my mantra in life; woven like a pattern embedded into my blood, heart and voice.

\section{The Navigator}

In the early 1990s, I was around fourteen or fifteen years of age when New Zealand's largest gay nightclub opened - Don't Tell Mama (DTM) (Hill, 2016) on Karangahape Road. It was a massive affair for the LGBTQI community, located in a historic building formerly known as the 1930s Picture Theatre Vogue (Hill, 2016). A security firm employed my first cousin as a head bouncer, and he recruited my older brother to work with him.

A month after it opened my cousin came to visit my mother and ask if he could take me to work for him at the club, he believed I was gay. My mother had no choice in the matter. My job was to work in a tiny kitchen on the fourth level making hot chips, nachos and fried snacks for intoxicated and hungry punters. I felt like I was in a fishbowl viewing people that seemed like caricatures from

12 Trixie Etuata (Former Member of Parliament Niue Island - deceased) in discussion with the author in 2003. 
a book. My perspective at the time was through rose coloured glasses; it was very foreign and unfamiliar to me. I have spent thirty years of my life immersed in the Rainbow community. The origins of this homogenous Rainbow community are very foreign and an identity label created by a man named Gilbert Baker (Blotcher, 1978), the Rainbow flag designer, who probably did not know where Niue is geographically situated nor what a fakafifine is. I left this job feeling like I did not belong there.

I spent most of my childhood seeking people like myself; no one seemed to understand me. At the age of sixteen, I was walking down Chinese Market Hill (Moger, 2019) in Grey Lynn, along the back of Grey Lynn Primary School. I heard echoes of a referee's whistle screeching. I followed the echoes of faint laughter and yelling. As I arrived closer, a netball game underway, played by athletic Polynesian women. I sat from afar and observed in awe. They were like gazelles prancing with such speed and agility. A player called me over, it was apparent I was very feminine in my mannerisms, she said to me "Hi sister", from that moment it was like seeing a reflection of myself for the first time.

All of these women were Samoan fa'afafine; they used netball as a support system to exercise, convene club obligations and to practice netball. I lived not far from the training courts, and they invited back to train. Although I had connections with people in my family, the connection I felt with these women was so affirming.

The Fono Fale model uses the floor of the fale to depict the foundation of a fale Samoa. A representation of family connection by kin, relationships and genealogy which connects them to titles, land, sea and gods (PulotuEndemann, 2001). I felt connected to these women and they would become my support system and my second 
family. I learnt the importance of usoga ${ }^{13}$ - sisterhood. This sisterhood provided me with peers who were intent on making me the prettiest woman I could be.

Walking in life without purpose can be a very lonely path to walk. My journey up until that point of meeting my new found sisters was lonely and confusing. I had no idea what I was searching for, and I did not see my fakafifine self in any family members. I had no course strategy and was sailing aimlessly and lost at sea. I owe my fakafifine sense of belonging to my fa'afafine sisters who provided me with courage and an understanding of my identity-an identity I had been searching for.

I did not learn from them that I was a transgender person, a gay boy, nor a Samoan, I learnt about the importance of my identity, that I am a Niuean first before anything else. They reminded me that although we can be viewed as deviants and lepers of society, no matter how hard others try they can never strip away the fact we are who we are (Samoan or Niuean), as it is in our blood and who our ancestors were ${ }^{14}$.

In 1995, at nineteen, I began to lose friends who were dying from AIDS-related illnesses. It was a shocking reality. Three years after meeting my social circle of friends, some of them were on their death beds. In 1996, we started to rally with others in the community and began working closely with the New Zealand AIDS Foundation who were predominately working with gay white men. We advocated, via our leaders Fuimaono Karl Pulotu-Endemann and Mama Tere Tahere-Strickland (New Zealand AIDS Foundation, 2010), to be included and supported as Pacific peoples.

In 2006, I commenced working for the Pacific Peoples Project as the community engagement officer promoting

\footnotetext{
13 Usoga - brotherhood.

${ }^{14}$ Barbara and Mahana were the two fa'afafine who welcomed me into their netball club.
} 
HIV/AIDS awareness in Pacific communities. My focus was breaking down stigma and discrimination associated with the disease (Brown-Acton, 2007) and in memory of my good friends that lost their lives to HIV/AIDS. My course strategy and pathway was becoming more apparent through these experiences.

In 2010, I attended the Asia Pacific Games Human Rights Conference as a keynote speaker. I listened to a keynote speech delivered by a former Member of Parliament and global feminist, Marilyn Waring. She warned people about the overuse of the term LGBTQI+ as it could be harmful to other movements who do not identify with this Western construct or labelling. I agreed with her, and so did many others there. I stayed up all night long redrafting my prepared speech, sharing ideas across the Tasman Sea with sister Tuisina Ymania Brown.

The following morning I presented and exclaimed that the use of Pacific identity terms is invisible in the LGBTQI+ narrative. I presented the mnemonic MVPFAFF ${ }^{15}$ and argued the importance of recognising and using Pacific terms in LGBTQI+ conversations, politics and advocacy. Marilyn was overcome with emotion by my speech, reaching out to hug me in tears. Marilyn later acknowledged me and other Pacific women in a written piece.

The intention of this paper was to acknowledge a few people of the many that have helped me to navigate the journey of life. I draw from these life experiences and influences that have moulded and guided me in life and work. I was not institutionalised by a school or a university as I left school at the age of fourteen. I have survived by learning from others, sitting at the feet of

\footnotetext{
15 Mahu, Vakasalewalewa, Palopa, Fa'afafine, Akava'ine, Fakafifine and Fakaleiti/leiti
} 
others, weaving and dancing with others, nurturing and sharing with others. 


\section{References}

Blotcher, J. (1978). Rainbow Flag: Gilbert Baker, Origin Story.

https://www.chicagoreviewpress.com/blog/apromise-kept-editing-gilbert-bakers-memoirrainbow-warrior/

Brown-Acton, P. (2007). Pacific Island Sexual Minority Gathering: Love Life Fono 2. Scoop Politics. https://www.scoop.co.nz/stories/PO0710/S0029 5.htm

Government House. (2019). Phylesha Brown-Acton, of Auckland, MNZM, for services to the Pacific and LGBTQI+

comminities.

https://gg.govt.nz/file/27805

Hill, J. (2016). Dark side of the Rori. https:/ / www.noted.co.nz/life/life-life-in-nz/darkside-of-the-rori

Low, $\mathrm{S}$. (1983).

The

Navigators. https://video.alexanderstreet.com/search?q=The Navigators

Moger, L. (2019). "Chinamans Hill” bus stop name shows "normalised racism", Auckland man says _ Stuff. https://www.stuff.co.nz/national/111637666/chi namans-hill-bus-stop-name-shows-normalisedracism-auckland-man-says

Museum of New Zealand Te Papa Tongarewa. (n.d.). Venice Biennale. Retrieved May 10, 2020, from https://www.tepapa.govt.nz/learn/foreducators/teaching-resources/venicebiennale/new-zealand/what-is-the-venicebiennale

New Zealand AIDS Foundation. (2010). Life Membership NZAF: Mama Tere Tahere Strickland. https://www.nzaf.org.nz/life-membership/

Polynesian Voyaging Society. (2020). Polynesian Wayfinding.

Pulotu-Endemann, K. (2001). Fonofale - Model of Health. https://d3n8a8pro7vhmx.cloudfront.net/actionpo 
int/pages / 437/attachments / original/ 153440895

6/Fonofalemodelexplanation.pdf? 1534408956 